https://helda.helsinki.fi

\title{
Metal contamination at a wood preservation site : characterisation and experimental studies on remediation
}

\section{Bhattacharya, $\mathrm{P}$.}

Elsevier Science B.V.

2002

Bhattacharya, P. et al. 2002. Metal contamination at a wood preservation site:

characterisation and experimental studies on remediation. The Science of the Total

pÿEnvironment 290: 165180.

http://hdl.handle.net/1975/226

Downloaded from Helda, University of Helsinki institutional repository.

This is an electronic reprint of the original article.

This reprint may differ from the original in pagination and typographic detail.

Please cite the original version. 


\title{
Metal contamination at a wood preservation site: characterisation and experimental studies on remediation
}

\author{
Prosun Bhattacharya ${ }^{\mathrm{a}, *}$, Arun B. Mukherjee ${ }^{\mathrm{b}}$, Gunnar Jacks ${ }^{\mathrm{a}}$, Sune Nordqvist ${ }^{\mathrm{c}}$ \\ ${ }^{a}$ Division of Land and Water Resources, Royal Institute of Technology, SE-100 44 Stockholm, Sweden \\ ${ }^{\mathrm{b}}$ Department of Limnology and Environmental Protection, P.O. Box 62 FIN-00014 University of Helsinki, Helsinki, Finland \\ ${ }^{\mathrm{c}}$ Terramek AB, Box 3129, SE-136 03 Haninge, Sweden
}

Received 8 May 2001; accepted 28 September 2001

\begin{abstract}
The aim of this investigation was to determine the occurrence of $\mathrm{As}, \mathrm{Cu}, \mathrm{Cr}$ and $\mathrm{Zn}$ in the soil at an abandoned wood preservation unit and to examine some possible extractants for the contaminants in the soil. The mean As content of the contaminated surface soils $(0-10 \mathrm{~cm})$ was $186 \mathrm{mg} \mathrm{kg}^{-1}$, where as the mean concentrations of $\mathrm{Cu}, \mathrm{Cr}$ and $\mathrm{Zn}$ in soils from the contaminated area were 26,29 and $91 \mathrm{mg} \mathrm{kg}^{-1}$, respectively. The elevated As content in the mineral soils is related to adsorption of inorganic As phases in the fine grained fractions, which are characterised by large surface area and high positive surface charge under the current acidic conditions. $\mathrm{Cu}$ and $\mathrm{Cr}$ were found to be rather mobile, which is reflected in their lower abundance in soils and significant accumulation in sediments in the drainage leaving the area. The fine fraction of the soil $(<0.125 \mathrm{~mm})$ has an average metal content increased by nearly $34 \%$ as compared to the $<2-\mathrm{mm}$ fraction conventionally used for the analysis and assessment of soil contamination. The $<2-\mathrm{mm}$ fraction constitutes approximately $65 \%$ of the total weight while the fine fraction $(<$ $0.125 \mathrm{~mm}$ ) constitutes approximately $10 \%$. These facts, taken together, are essential for the choice of remediation measures. Oxalate solutions have been tested as extractants for soil remediation. Dark acid oxalate extraction dissolves the amorphous Al- and Fe-oxides and hydroxides and mobilises the adsorbed inorganic As species. Oxalate also acts as a ligand for the cationic heavy metals, releasing them from exchangeable sites. With a three-step sequential leaching, up to $98-99 \%$ of the metals could be removed. At lower concentrations and higher $\mathrm{pH}$, the leaching decreased to approximately 70\%. (c) 2002 Elsevier Science B.V. All rights reserved.
\end{abstract}

Keywords: Arsenic; Chromium; Copper; Zinc; Wood preservation; CCA; Soil; Chemical remediation

\section{Introduction}

Wood preservation industries have been operating in Sweden since the middle of the 19th century to protect wood from bacterial, fungal and insect attack (Jacks and Bhattacharya, 1998). Chemicals such as copper sulfate, Boliden salt (BIS-salt)

*Corresponding author. Tel.: +46-8-790-7399.

E-mail address: prosun@aom.kth.se (P. Bhattacharya). mixed with zinc sulfate and chromated copper arsenate (CCA) have been used as common wood preservative for more than 50 years (Jacks and Bhattacharya 1998). However, pressure treatment with CCA has grown drastically over the past 20 years (Stephens et al., 1994) and has remained as the most preferred industrial method of wood preservation in Sweden. It has replaced the conventional use of pentachlorophenol (PCP) and 
Table 1

Some of the common water soluble As-based chemicals used for wood preservation in Sweden (Jacks and Bhattacharya, 1998)

\begin{tabular}{|c|c|c|c|c|c|}
\hline Chemical & Year & Composition (\%) & Percen & al in & \\
\hline $\begin{array}{l}\text { Boliden BIS } \\
+\mathrm{ZnSO}_{4}\end{array}$ & $1936-1950$ & $\begin{array}{l}\mathrm{Zn}(\mathrm{II}) \text { oxide }(\mathrm{ZnO}) \\
\text { Chromium trioxide }\left(\mathrm{CrO}_{3}\right) \\
\text { Diarsenic pentoxide }\left(\mathrm{As}_{2} \mathrm{O}_{5}\right) \\
\text { Sodium }(\mathrm{I}) \text { oxide }\left(\mathrm{Na}_{2} \mathrm{O}\right) \\
\text { Sulfur trioxide }\left(\mathrm{SO}_{3}\right)\end{array}$ & $\begin{array}{r}12.0 \% \\
10.5 \% \\
27.7 \% \\
9.2 \% \\
28.5 \%\end{array}$ & $\begin{array}{l}\mathrm{Zn} \\
\mathrm{Cr} \\
\mathrm{As}\end{array}$ & $\begin{array}{r}9.8 \% \\
5.5 \% \\
18.1 \%\end{array}$ \\
\hline Boliden S25 & $1951-1954$ & $\begin{array}{l}\mathrm{Zn}(\mathrm{II}) \text { oxide }(\mathrm{ZnO}) \\
\text { Copper(II) oxide }(\mathrm{CuO}) \\
\text { Chromium trioxide }\left(\mathrm{CrO}_{3}\right) \\
\text { Diarsenic pentoxide }\left(\mathrm{As}_{2} \mathrm{O}_{5}\right) \\
\text { Water }\left(\mathrm{H}_{2} \mathrm{O}\right)\end{array}$ & $\begin{array}{r}11.6 \% \\
3.9 \% \\
23.0 \% \\
36.0 \% \\
25.5 \%\end{array}$ & $\begin{array}{l}\mathrm{Zn} \\
\mathrm{Cu} \\
\mathrm{Cr} \\
\mathrm{As}\end{array}$ & $\begin{array}{r}9.3 \% \\
3.1 \% \\
12.0 \% \\
23.5 \%\end{array}$ \\
\hline $\begin{array}{c}\mathrm{K} 33, \mathrm{CCA} \\
\text { type B }\end{array}$ & $1952-1990$ & $\begin{array}{l}\text { Copper }(\mathrm{II}) \text { oxide }(\mathrm{CuO}) \\
\text { Chromium trioxide }\left(\mathrm{CrO}_{3}\right) \\
\text { Diarsenic pentoxide }\left(\mathrm{As}_{2} \mathrm{O}_{5}\right) \\
\text { Water }\left(\mathrm{H}_{2} \mathrm{O}\right)\end{array}$ & $\begin{array}{l}14.8 \% \\
26.6 \% \\
34.0 \% \\
24.6 \%\end{array}$ & $\begin{array}{l}\mathrm{Cu} \\
\mathrm{Cr} \\
\mathrm{As}\end{array}$ & $\begin{array}{l}11.8 \% \\
13.8 \% \\
22.2 \%\end{array}$ \\
\hline $\begin{array}{l}\text { Celcure/C33 } \\
\quad \text { (or equivalents) }\end{array}$ & $1983-1990$ & $\begin{array}{l}\text { Copper(II) sulfate }\left(\mathrm{CuSO}_{4} .5 \mathrm{H}_{2} \mathrm{O}\right) \\
\text { Copper(II) oxide }(\mathrm{CuO}) \\
\text { Chromium trioxide }\left(\mathrm{CrO}_{3}\right) \\
\text { Diarsenic pentoxide }\left(\mathrm{As}_{2} \mathrm{O}_{5}\right) \\
\text { Water }\left(\mathrm{H}_{2} \mathrm{O}\right)\end{array}$ & $\begin{array}{r}23.2 \% \\
2.8 \% \\
40.0 \% \\
22.7 \% \\
11.3 \%\end{array}$ & $\begin{array}{l}\mathrm{Cu} \\
\mathrm{Cr} \\
\mathrm{As}\end{array}$ & $\begin{array}{l}8.2 \% \\
14.0 \% \\
14.8 \%\end{array}$ \\
\hline
\end{tabular}

creosote, which are a complex and variable mixture produced from coal (Jacks and Bhattacharya, 1998). However, among the 130 wood preservation industries presently operating in Sweden, only three units are using creosote as a preservative, 24 units use artificial oils and the rest use different water soluble inorganic salts approved by the Nordic Council for Wood Preservation, based on arsenic, copper, chromium and zinc (Table 1).

The use of CCA and other As-based chemicals as wood preservatives in Sweden have caused widespread metal contamination in soils around the wood preservation sites due to raw material handling, spills, deposition of sludge and dripping from freshly impregnated wood or due to leaching from the piles of impregnated wood at these sites by rain water especially under low $\mathrm{pH}$ conditions (Lund and Fobian, 1991; Warner and Solomon, 1990; Andersen et al., 1996; Bhattacharya et al., 1996). Mechanisms of retention and mobility of metals in soils have been studied extensively by many authors (Adriano, 1986; Kabata-Pendias and Pendias, 2001), but studies pertaining to the behaviour of complex mixes of metal contaminants (As,
$\mathrm{Cu}, \mathrm{Cr}$, and $\mathrm{Zn}$ ) in $\mathrm{CCA}$ contaminated soils under field conditions are few (Lund and Fobian, 1991; Bhattacharya et al., 1996; Stilwell and Gorny, 1997).

The site of a former wood preservation facility at Konsterud in Kristinehamn Community in central Sweden (Fig. 1) was selected as an object for the present investigations on metal contamination in the soils, where BIS-salt and CCA had been used extensively. Following the detection of As in an adjacent drinking water well, remediation of the site was considered by the local community. Hence, the purpose of this study was two-fold: (a) to ascertain the extent of metal contamination (As, $\mathrm{Cu}, \mathrm{Cr}$, and $\mathrm{Zn}$ ) in the soil in the area; and (b) to develop techniques for the removal of contaminant metals in the vicinity of the impregnation facility.

\section{CCA metals in soil environment and their removal}

\subsection{Chemistry of CCA metals in soils}

The chemicals such as the mixture of Boliden (BIS) and zinc sulfate and CCA used for industrial 


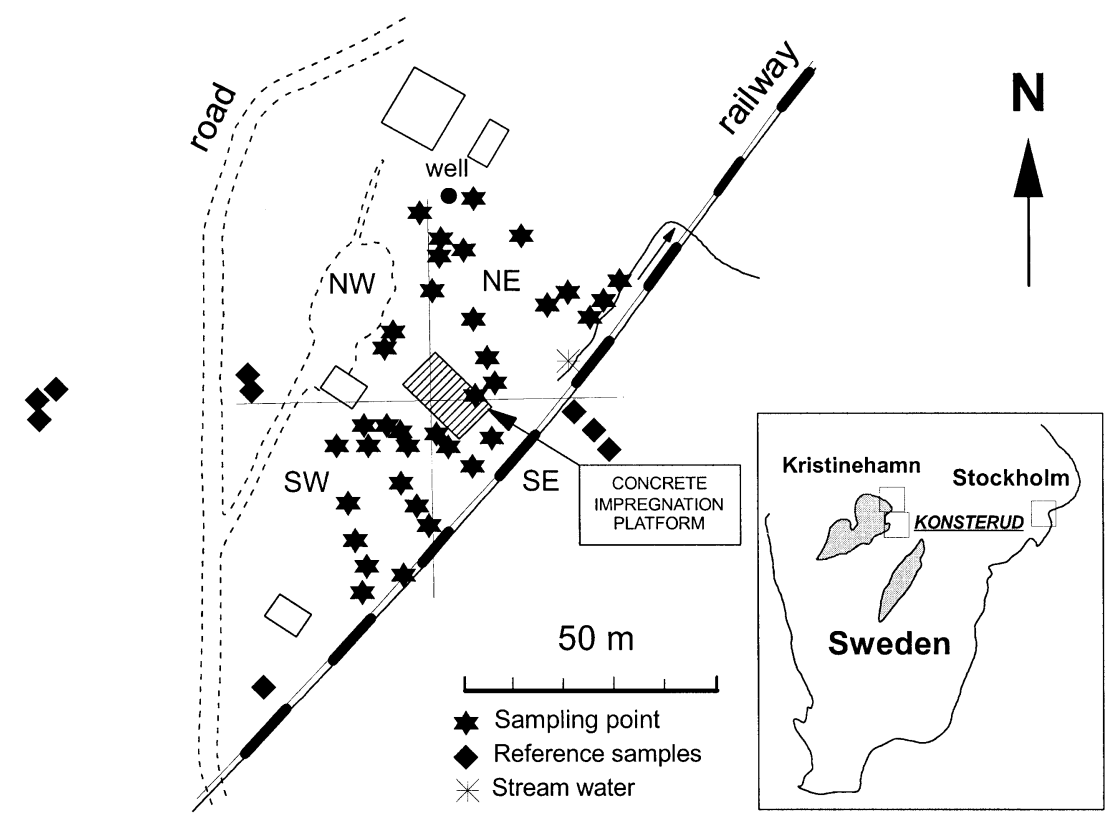

Fig. 1. Location map of the site of wood preservation at Konsterud, Kristinehamn Community, central Sweden along with the sampling plan.

wood preservation have contributed the toxic elements such as $\mathrm{As}, \mathrm{Cu}, \mathrm{Cr}$ and $\mathrm{Zn}$ in the soils environment. Bioavailability of these metals in contaminated soils may vary according to $\mathrm{pH}$, redox conditions and the quantity of organic matter in the soils, and due to changes in the land use pattern. The mobility of the metals are generally controlled by precipitation, diffusion, volatilization and dissolution of unstable minerals (Kabata-Pendias and Pendias, 2001), besides other surface complexation processes. The sorption of anionic contaminants such as As differs significantly from those of cationic contaminants $\mathrm{Cu}, \mathrm{Cr}$ and $\mathrm{Zn}$ depending on soil $\mathrm{pH}$ and redox conditions (Eh). The fate of CCA contaminants thus varies widely in soil environments.

Arsenic is widely distributed in soils and with average concentrations in the range of $1-40 \mathrm{mg}$ $\mathrm{kg}^{-1}$, with a mean value of approximately $5 \mathrm{mg}$ $\mathrm{kg}^{-1}$ (Eckel and Langley, 1988; Yan Chu, 1994). In Swedish tills, $(<0.06 \mathrm{~mm})$, the As content ranges between $<5$ and $175 \mathrm{mg} \mathrm{kg}^{-1}$ with a median value of $8 \mathrm{mg} \mathrm{kg}^{-1}$ (Geological Survey of Sweden, personal communication, 1999). The background As concentration in soils is controlled by the lithology of the parent rocks (Yan Chu, 1994) and it is important to assess this in a given area prior to remediation. In view of the potential risk of bioaccumulation and toxicity of As (Bhumbla and Keefer, 1994; Bhattacharya et al., 1997, 2001), the geochemical behaviour of As in nature has generated much concern in environmental research in recent years.

Under the range of $\mathrm{Eh}$ and $\mathrm{pH}$ in soil compartments, As normally occurs in + III and $+\mathrm{V}$ oxidation states (Cullen and Reimer, 1989). As(III), $\mathrm{H}_{3} \mathrm{AsO}_{3}^{0}$ or $\mathrm{H}_{2} \mathrm{AsO}_{3}^{-}$dominates under reducing conditions $(\mathrm{pe}+\mathrm{pH}<8$ ) which is more toxic and more mobile as compared to the $\mathrm{As}(\mathrm{V})$, $\mathrm{H}_{2} \mathrm{AsO}_{4}^{-}$or $\mathrm{HAsO}_{4}^{2-}$ forms, which are prevalent under oxidising conditions ( $\mathrm{pe}+\mathrm{pH}>8$ ) (Sadiq et al., 1983; Masscheleyn et al., 1991).

An increased As content has been noted with increasing clay content of the contaminated soils (Galba and Polacek, 1973). Preferential sorption of $\mathrm{As}(\mathrm{V})$ on clay minerals like kaolinite, illite and montmorillonite occurs at $\mathrm{pH} 2-<8$, while As(III) sorbs preferentially at $\mathrm{pH}$ 8-10 (Manning and Goldberg, 1997). The geochemical behaviour of $\mathrm{As}(\mathrm{V})$ and $\mathrm{P}$ are strikingly similar and are 


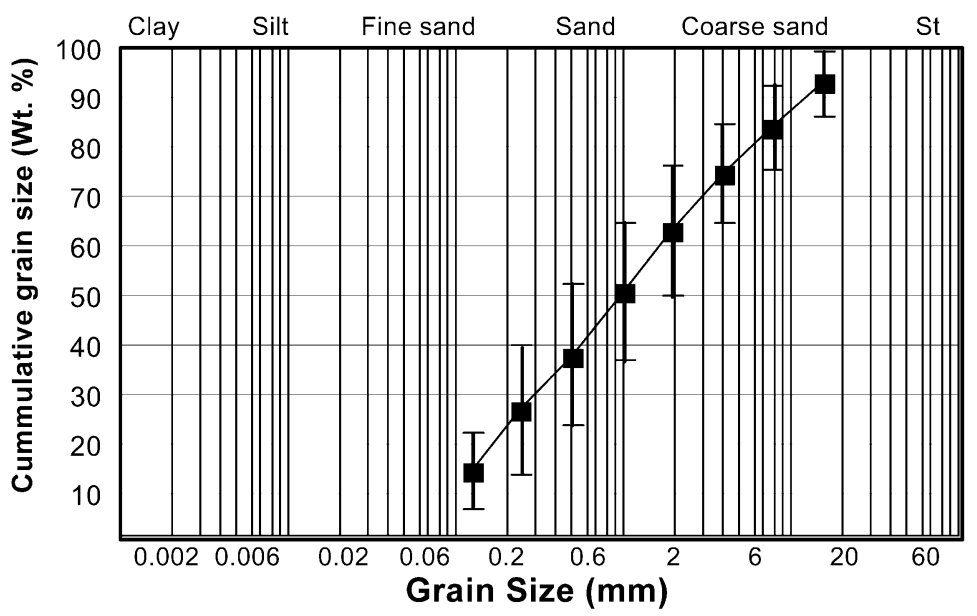

Fig. 2. Average grain size distribution in the contaminated soils from Konsterud $(n=36)$. The bars indicate the range of variation in the respective grain size fractions.

adsorbed on the oxides of $\mathrm{Al}, \mathrm{Fe}$ and, under specific circumstances, even with Mn (Manning and Goldberg, 1996). Imogolite-type materials (ITM) and ferrihydrite occurring in the podzolic B-horizon are characterised by a large surface area and high positive surface charge in an acidic environment and account for the sorption of the bulk of As(V) (Gustafsson et al., 1995).

The solubility of $\mathrm{Cu}$ and $\mathrm{Zn}$ is governed by the $\mathrm{pH}$ and redox conditions and in the $\mathrm{pH}$ range of 5.4-6.5, $\mathrm{Cu}$ and $\mathrm{Zn}$ are distinctly more soluble under oxidising conditions than reducing conditions (Hermann and Neumann-Mahlkau, 1985). $\mathrm{Cu}$ is complexed by the organic ligands, especially by the carboxylic and phenolic groups (Tipping, 1993). As the solubility of organic matter increases with increasing $\mathrm{pH}$, the dissociation of $\mathrm{Cu}$-organic matter complexes can result in the leaching of $\mathrm{Cu}$ to groundwater. On the other hand, in the soil environments, $\mathrm{Cr}$ occurs in oxidation states $\mathrm{Cr}$ (III) and $\mathrm{Cr}(\mathrm{VI})$, which govern its mobility and toxicity (Bartlett and James, 1979). In Cr(III)-dominated systems, the prevalent species is $\mathrm{CrOH}^{2+}$ at $\mathrm{pH}$ 2-6, $\mathrm{Cr}(\mathrm{OH})_{3}^{0}$ at $\mathrm{pH}$ 6.5-11.5 and $\mathrm{Cr}(\mathrm{OH})_{4}^{-}$at $\mathrm{pH}>11.5$ (Sass and Rai, 1987). In the presence of $\mathrm{Fe}$ (III) in geological environments, the solubility of $\mathrm{Cr}$ (III) is ubiquitously controlled by the solid solution $(\mathrm{Cr}, \mathrm{Fe})(\mathrm{OH})_{3}$ (Sass and Rai, 1987).
The adsorption of $\mathrm{Cr}(\mathrm{VI})$ increases with decreasing $\mathrm{pH}$ due to the protonation of surface hydroxyl groups on mineral solids (Rai et al., 1989), including the imogolite type materials (ITM) in the podzolic B-horizon (Lindberg et al., 1997).

\subsection{Principles of remediation of contaminated soils}

Soil remediation techniques depend on the concentration and physical state of the contaminants, the type of soil, grain size distribution, and content of organic matter. In recent years, traditional cleaning techniques, such as molecular and phase separation, chemical destruction, vapour extraction, electrokinetics and biodegradation are often practised (Saxen et al., 1999). All these techniques can be successfully applied if the physicochemical properties of pollutants and soil particles are well understood before selecting any methods (Rulkens et al., 1998; Adriano et al., 1998). However, mobilisation of the metals from the contaminated soils by soil-washing using suitable extractants has been envisaged as one of the potential methods for soil remediation (Bourg, 1983; Tessier et al., 1985).

Metals are mobilised through acidification, and the effects of $\mathrm{pH}$ on metal solubility have been 
demonstrated by several investigations throughout the world (e.g. Smal, 1994; Bhattacharya et al., 1996; Kedziorek and Bourg, 1996). Geochemical processes that control solubility and the subsequent removal of heavy metals from the contaminated soils during chemical remediation could be attributed to desorption from the surface-reactive soil components, dissolution of the unstable mineral phases (i.e. carbonates and other metal-oxides) and the formation of soluble metal-complexes. Finer grain size fractions possess a greater surface area, and thereby adsorb the bulk of the heavy metals onto their surfaces. Since the fine grained fraction comprises, to a major extent, clay minerals, non-crystalline aluminosilicate phases (ITM) and amorphous Fe-oxides and hydroxides, it sorbs the anionic contaminants such as $\mathrm{AsO}_{4}^{2-}$ and $\mathrm{AsO}_{3}^{2-}$ as a function of $\mathrm{pH}$ (Gustafsson et al., 1995; Bhattacharya et al., 1996). In a similar way, the organic ligands also have the capacity to bind other cationic metal species. Moreover, the higher incidences of metals in the fine-grained fractions also reduce the volume of contaminated soils during remediation. In recent years, the soil washing technique has been successfully applied to remove heavy metals (such as $\mathrm{Pb}, \mathrm{Cd}, \mathrm{Cr}, \mathrm{Cu}, \mathrm{Ni}$ and $\mathrm{Hg}$ ) from contaminated soils in the western world where the generation of hazardous wastes have been avoided (Fristad, 1995).

\section{Material and methods}

\subsection{Field characteristics}

The impregnation industry (area $5000 \mathrm{~m}^{2}$ ) was established in approximately 1940 and was in operation until 1968. The facility was later destroyed by fire in 1974 . The only remnant of the industry is a concrete platform on which the preservative chemical tank was placed. The area is presently fringed by forest to the north, a service road towards south and a meadow towards the south-east, separated from the contaminated area by an old railway embankment. The land is presently owned privately and used for residential purposes.
Podzolic sandy soil profiles with thin organic horizons are developed up to a depth of approximately $0.5-1.0 \mathrm{~m}$, underlain by silty-clayey till and sediments resting on the basement rocks up to depths of 1-3 m. A thick grey clay layer at the bottom was exposed as a consequence of the removal of the concrete platform. The area has been repeatedly excavated which has caused considerable mixing of the contaminated soils. The pits in the area had been filled by organic materials, mainly wooden chips and saw dust. The groundwater levels in the observation wells indicate an eastward flow direction. A surface stream emerges east of the concrete platform with a northeasterly flow direction (Fig. 1).

\subsection{Field investigations and sampling}

In order to estimate and delineate the metal contamination in the area, 67 soil samples were collected in a $10-\mathrm{m}^{2}$ grid pattern from 38 points from the site (Fig. 1) during August, 1995. Sample representation from individual grids varied considerably due to hinders in the form of large boulders, roads and locally built cottages as well as other disturbances such as pre-excavations in certain parts. In general, 2-3 samples were taken from all possible undisturbed grids in the area. The soils were mainly collected by a sharp-edged auger from the top soil layer $(0-0.1 \mathrm{~m})$. Hand auger was used for the sampling of soil profiles at depths of $0.2-0.4,0.4-0.5$ and $1.7 \mathrm{~m}$.

The area has been grouped into four sectors, in relation to the concrete impregnation platform (see Fig. 1) and site characteristics. The soils were relatively undisturbed towards the south-west, while the area towards east and south-east was highly disturbed due to excavations. The area towards north-east was filled with wooden chips and saw mill dust $(\mathrm{WCH})$ with a maximum depth of approximately $1.7 \mathrm{~m}$. Reference soil samples were collected from a meadow towards the southeast as well as from a few selected points away from the contaminated area to the west and southwest. The sediment samples (SST) were collected from a stream adjoining the railway embankment at the south-eastern end of the area. The water 
sample collected from the stream was filtered through a $0.45-\mu \mathrm{m}$ Sartorius online filter and acidified with $0.5 \mathrm{ml}$ of concentrated $\mathrm{HNO}_{3}$ for analysis.

\subsection{Laboratory investigations}

The laboratory investigations included the determination of soil moisture content, texture, loss on ignition (LOI) and soil chemical parameters such as $\mathrm{pH}$ and Eh. Soil $\mathrm{pH}$ was measured in a slurry with 1:2.5 soil/solution ratio, following the guidelines of the Nordic Council of Ministers (1988) using a Radiometer Copenhagen combination electrode (pHC2401-7). The soil redox potential (Eh) was measured using a platinum electrode $(\mathrm{M} 241 \mathrm{Pt})$ and a calomel reference electrode (REF401) submerged in the soil slurry in a enclosed cell on a Radiometer Copenhagen PHM 80 instrument. The $\mathrm{pH}$ and Eh values were noted after stabilisation of the electrodes. In general, a minimum of 15-20 min was allowed for the stabilisation of the Eh readings. At $20{ }^{\circ} \mathrm{C}$ and in saturated $\mathrm{KCl}$, the standard potential of the calomel electrode was $+244 \mathrm{mV}$ (Appelo and Postma 1993) which was subtracted from the measured Eh values.

The analytical work involved determination of $\mathrm{As}, \mathrm{Cu}, \mathrm{Cr}$ and $\mathrm{Zn}$ in the $<2-\mathrm{mm}$ and $<0.125-$ $\mathrm{mm}$ grain size fractions of the soils extractable by $7 \mathrm{M} \mathrm{HNO}_{3}$ (referred hereafter as total metals). Two grams of contaminated soil samples were digested with $15 \mathrm{ml} 7 \mathrm{M} \mathrm{HNO}_{3}$ for $2.5 \mathrm{~h}$ on a temperature controlled sandbath at $70{ }^{\circ} \mathrm{C}$ for the first $30 \mathrm{~min}$, and later at $100{ }^{\circ} \mathrm{C}$ for the next $2 \mathrm{~h}$. After cooling, the samples were filtered through OOK filter paper and made to a volume of $50 \mathrm{ml}$ (Andersson et al., 1991).

Sequential leaching batch experiments devised for soil washing were carried out using oxalic acid (OXA) with $0.4,0.5$ and $0.7 \mathrm{M}$ concentrations and ammonium oxalate (AMOX) solution buffered with oxalic acid at $\mathrm{pH} 1.4,2.5$ and 4.0 with the objective of quantifying the removal of $\mathrm{As}, \mathrm{Cu}$, $\mathrm{Cr}$ and $\mathrm{Zn}$ from the contaminated soils. Oxalate was considered a suitable extracting agent for chemical remediation of the contaminated soils, because: (i) it forms a complex with positively charged heavy metals and is a strong reducing/ chelating agent for $\mathrm{Fe}$ - and Al-oxides and hydroxides (Tamm, 1932); and (ii) it is biodegradable and occurs naturally in soils (Fox and Comerford, 1990).

Fine grained fraction $(<0.125 \mathrm{~mm})$ of the mineral soil samples, Kc-32 ( $\mathrm{pH} \mathrm{5.6)}$ and $\mathrm{Kc}-45$ $(\mathrm{pH} 4.9)$ were tested for metal leaching. Five grams of air dried contaminated soil samples were extracted with the different solutions (1:50; solid/ solution ratio) following horizontal shaking for a period of $5 \mathrm{~min}$ and filtered through OOK filter paper and the filtrate was further filtered using $0.45 \mu \mathrm{m}$ online filters for analysis. The residual batches from the first leaching were further extracted twice and the filtrates were analysed for the metal contents. A Jobin Yvon (JY 24) sequential inductively coupled plasma (ICP) spectrophotometer was used for the analyses of metals in soil extracts and the water samples and the precision of analyses was $\pm 1 \mathrm{mg} \mathrm{kg}^{-1}$ for the analysed metals.

\section{Analytical results}

\subsection{Grain size distribution and LOI}

Average grain size distribution based on 36 analyses of the soils from the contaminated site at Konsterud (Fig. 2) indicates that the fraction $<2$ $\mathrm{mm}$ comprises $65 \%$ by weight. The fine grained fraction $(<0.125 \mathrm{~mm})$ constitutes on an average $10 \%$. The content of organic matter was estimated by LOI and varied between 9 and 13\%. The stream sediment, however, indicated high content of organic matter with LOI as high as $23 \%$.

\subsection{Soil chemical parameters}

\subsection{1. $\mathrm{pH}$ and redox potential (Eh)}

The $\mathrm{pH}\left(\mathrm{H}_{2} \mathrm{O}\right)$ ranges from 4.55 to 7.25 (av. $5.67 \pm 1.08)$ in the mineral soils, indicating generally acidic conditions in the contaminated area (Table 2). The acidic character of the mineral soils is more pronounced in the north-eastern sector where $\mathrm{pH}$ values are the lowest. The organic fills (wooden chip) in this sector also indicated low $\mathrm{pH}$ in the range of 4.34-5.07 with an average of $4.71 \pm 0.37$. The $\mathrm{pH}$ of the reference soils (av. 
Table 2

$\mathrm{pH}$, redox potential (Eh in $\mathrm{mV}$ ) and concentrations of $\mathrm{As}_{\mathrm{tot}}, \mathrm{Zn}_{\mathrm{tot}}, \mathrm{Cu}_{\mathrm{tot}}$ and $\mathrm{Cr}_{\mathrm{tot}}\left(\mathrm{mg} \mathrm{kg}{ }^{-1}\right)$ in the average contaminated mineral soils, organic fills, stream sediments and reference soils from the wood preservation site at Konsterud, Central Sweden

\begin{tabular}{|c|c|c|}
\hline Parameter & $<2 \mathrm{~mm}^{\mathrm{a}}$ & $<0.125 \mathrm{~mm}^{\mathrm{a}}$ \\
\hline \multicolumn{3}{|c|}{ Average contaminated mineral soils $(n=54)$} \\
\hline $\mathrm{pH}\left(\mathrm{H}_{2} \mathrm{O}\right)$ & $4.55-7.25(5.67,5.49)$ & \\
\hline Eh & $-134-+18(-61,-64)$ & \\
\hline $\mathrm{As}_{\text {tot }}$ & $10-1067(186,121)$ & $45-1627(282,224)$ \\
\hline $\mathrm{Zn}_{\text {tot }}$ & $6-388(91,64)$ & $9-724(149,112)$ \\
\hline $\mathrm{Cr}_{\text {tot }}$ & $3-153(29,18)$ & $6-233(51,33)$ \\
\hline $\mathrm{Cu}_{\text {tot }}$ & $10-74(26,21)$ & $12-289(56,43)$ \\
\hline \multicolumn{3}{|c|}{ Organic fills (wooden chips) $(n=6)^{\mathrm{b}}$} \\
\hline $\mathrm{pH}\left(\mathrm{H}_{2} \mathrm{O}\right)$ & $4.34-5.07(4.71,4.73)$ & \\
\hline Eh & $-70.5--18.7(-50.1,-61)$ & \\
\hline $\mathrm{As}_{\text {tot }}$ & $98-465(237,190)$ & 255 \\
\hline $\mathrm{Zn}_{\text {tot }}$ & $37-245(125,99)$ & 112 \\
\hline $\mathrm{Cr}_{\text {tot }}$ & $25-148(83,80)$ & 89 \\
\hline $\mathrm{Cu}_{\text {tot }}$ & $6-88(42,41)$ & 106 \\
\hline \multicolumn{3}{|c|}{ Average stream sediments $(n=3)$} \\
\hline $\mathrm{pH}\left(\mathrm{H}_{2} \mathrm{O}\right)$ & $5.51-5.91(5.67,5.58)$ & \\
\hline Eh & $-96.6--60.3(-73,-61)$ & \\
\hline $\mathrm{As}_{\text {tot }}$ & $103-1681(632,111)$ & $3380-4460(3972,4077)$ \\
\hline $\mathrm{Zn}_{\text {tot }}$ & $179-6369(2393,631)$ & $594-8158(3330,1239)$ \\
\hline $\mathrm{Cr}_{\text {tot }}$ & $23-2647(1335,1335)$ & $34-5632(2670,2343)$ \\
\hline $\mathrm{Cu}_{\text {tot }}$ & $139-1772(1092,1366)$ & $653-1881(1465,1862)$ \\
\hline \multicolumn{3}{|c|}{ Average reference soils $(n=13)$} \\
\hline $\mathrm{pH}\left(\mathrm{H}_{2} \mathrm{O}\right)$ & $4.94-5.64(5.23,5,18)$ & \\
\hline $\mathrm{Eh}$ & $-95.9--73.7(-85,-86)$ & \\
\hline $\mathrm{As}_{\text {tot }}$ & $34-260(119,109)$ & $45-311(185,190)$ \\
\hline $\mathrm{Zn}_{\text {tot }}$ & $6-190(59,45)$ & 9-208 $(89,71)$ \\
\hline $\mathrm{Cr}_{\text {tot }}$ & $4-37(13,7)$ & $6-61(22,16)$ \\
\hline $\mathrm{Cu}_{\text {tot }}$ & $10-47(25,24)$ & $14-86(42,38)$ \\
\hline
\end{tabular}

${ }^{a}$ Values given in parentheses: mean, median.

${ }^{\mathrm{b}} n=1$ for the analysed fraction $<0.125 \mathrm{~mm}$.

$5.23 \pm 0.3)$ further supports the acidic character of the soils in the area.

The measured redox potential (Eh) of the contaminated soils varied between +18 and -134 $\mathrm{mV}$ with an average value of $-61 \mathrm{mV}$ (Table 2). The Eh-pH diagram presented in Fig. 3 depicts the stability fields of different inorganic contaminant metal species of $\mathrm{As}, \mathrm{Cu}, \mathrm{Cr}$ and $\mathrm{Zn}$ commonly occurring in the soil environment. The redox potential in the soil suspension suggests arsenic to be present in the reduced As(III) form (Fig. 3a) under the prevailing Eh-pH conditions in the soils at the contaminated site. Under the prevailing redox conditions in these soils $\mathrm{Cu}$ may be present in the reduced form, while $\mathrm{Zn}$ as $\mathrm{Zn}^{2+}$ species (Fig. 3b,d). A similar Eh-pH diagram for the different oxidation phases of $\mathrm{Cr}$ indicates the dominance of the trivalent state as $\mathrm{CrOH}^{2+}$ or as uncharged $\mathrm{Cr}(\mathrm{OH})_{3}^{0}$ species which is known to control the solubility of $\mathrm{Cr}$ under surface conditions (Fig. 3c).

\subsubsection{Metal contaminants in the soils}

The contaminant metals are found in the following order of abundance in the soils: $A s>\mathrm{Zn}>$ $\mathrm{Cr}>\mathrm{Cu}$ (Table 2). The mean and median concentration of metals in the contaminated mineral soils, organic fills, stream sediments and the 



Fig. 3. Eh-pH diagram showing the stability fields (at $25{ }^{\circ} \mathrm{C}$ and $1 \mathrm{~atm}$ total pressure) for the different contaminant metal species occurring at the site of wood preservation. (a) As- $\mathrm{H}_{2} \mathrm{O}-\mathrm{O}_{2}$ system, activity of As taken as $10^{-4}$ mol $1^{-1}$ (after Masscheleyn et al., 1991); (b) $\mathrm{Cu}-\mathrm{H}_{2} \mathrm{O}-\mathrm{O}_{2}-\mathrm{S}-\mathrm{CO}_{2}$ system, $\mathrm{PCO}_{2}=10^{-1}$ (after Garrels and Christ, 1965); (c) $\mathrm{Cr}-\mathrm{H}_{2} \mathrm{O}-\mathrm{O}_{2}$ system (after Rai et al., 1989); and (d) $\mathrm{Zn}-\mathrm{CO}_{2}-\mathrm{S}-\mathrm{H}_{2} \mathrm{O}$ system, activity of $\mathrm{Zn}$ taken as $10^{-5} \mathrm{~mol} 1^{-1}$, dissolved $\mathrm{CO}_{2}$ and $\mathrm{S}$ species, $10^{-3}$ mol $1^{-1}$ (from Hermann and Neumann-Mahlkau, 1985). Symbols: $\square$ NE sector (mineral soil); $\bigcirc$ NE sector (organic soil); $\bigcirc \mathrm{SE}$ sector; $\diamond \mathrm{SW}$ sector; $X$ stream sediments; + reference soils.

reference soils in the two grain size $<2 \mathrm{~mm}$ and $<0.125 \mathrm{~mm}$ fractions are presented in Table 2 . The fine grained $(<0.125 \mathrm{~mm})$ fraction, in general, reveals a higher metal concentration as compared to the coarser $(<2 \mathrm{~mm})$ fraction of the soils.

The mineral soils of the contaminated site revealed high concentration of total arsenic $\left(\mathrm{As}_{\text {tot }}\right)$ varying between $10 \mathrm{mg} \mathrm{kg}^{-1}$ and as high as 1067 $\mathrm{mg} \mathrm{kg}{ }^{-1}$ as compared to the total zinc $\left(\mathrm{Zn}_{\text {tot }}=6-\right.$ $\left.388 \mathrm{mg} \mathrm{kg}{ }^{-1}\right)$, chromium $\left(\mathrm{Cr}_{\text {tot }}=3-153 \mathrm{mg}\right.$ $\left.\mathrm{kg}^{-1}\right)$ and copper $\left(\mathrm{Cu}_{\mathrm{tot}}=10-74 \mathrm{mg} \mathrm{kg}{ }^{-1}\right)$. Such variations in the metal concentrations were also reflected in the fine-grained $(<0.125 \mathrm{~mm})$ fractions of the soils where the metal concentrations were higher than the corresponding $<2 \mathrm{~mm}$ fractions (Table 2).

A comparison between the mean and the median values for the analysed metals indicates considerable consistency in the nature of metal distribution in the area (Table 2). Analysis of $\mathrm{WCH}$ in the NE sector revealed higher $\mathrm{As}_{\text {tot }}$ and $\mathrm{Cr}_{\text {tot }}$ concentrations which is related to the retention of these metals in the treated wood. Analyses of the SST adjacent to the cemented platform with a high content of organic matter indicated accumulation 
of the metals due to the formation of metalorganic complexes. The dissolved concentration of metal species of $\mathrm{As}, \mathrm{Zn}$ and $\mathrm{Cu}$ in the stream water were quite appreciable and their respective concentrations were 238,243 , and $228 \mu \mathrm{g} \mathrm{l}^{-1}$. The $\mathrm{Cr}$ concentration was, however, negligible $(<$ $\left.10 \mu \mathrm{g} \mathrm{l}^{-1}\right)$.

\subsubsection{Geochemical variations along two selected soil profiles}

Variations in $\mathrm{pH}$, Eh and metal abundances in the two grain size fractions in two selected soil profiles from the contaminated site are presented in Fig. 4. Variations in the $\mathrm{pH}$ were not conspicuous in the selected soil profiles but the measured redox potential (Eh) was more reducing in the $\mathrm{NE}$ sector as compared to the undisturbed soil profile at the SW sector (Fig. 4a,b). A decrease in the concentration of the analysed metals $\mathrm{As}, \mathrm{Cu}, \mathrm{Cr}$ and $\mathrm{Zn}$ was observed up to a depth of $30 \mathrm{~cm}$. The metal contents increased in the Bs horizon at depths of $40-50 \mathrm{~cm}$, because of the greater adsorption capacity of the spodic horizons in these soil profiles (see Section 5). The metal contents however, decreased at further depths.

\subsubsection{Reference soil normalised plot}

In order to assess the extent of metal contamination in the area, the average metal contents in both the soil fractions have been normalised to the reference soils and plotted on variation diagrams (Fig. 5a,b). Reference soils were collected from locations outside the compounds of the preservation site both towards west as well as the east of the railway track (Fig. 1). The mean $\mathrm{As}_{\text {tot }}$ concentration $\left(119 \mathrm{mg} \mathrm{kg}^{-1}\right)$ in the reference samples collected from several locations adjacent to the contaminated area was lower than the average mineral soil at the wood preservation site, but exceeded the level of As in average glacial till (Koljonen, 1992). The $\mathrm{Zn}_{\text {tot }}$ content in the reference soils ( $59 \mathrm{mg} \mathrm{kg}^{-1}$ ) was close to background level (Edén and Björklund, 1995), while $\mathrm{Cu}_{\text {tot }}(25$ $\left.\mathrm{mg} \mathrm{kg}{ }^{-1}\right)$ and $\mathrm{Cr}_{\text {tot }}\left(13 \mathrm{mg} \mathrm{kg}{ }^{-1}\right)$ in the reference soils were comparable to the contaminated area as well as the analysed glacial tills (Geological Survey of Sweden, personal communication, 1999).
The reason for this is not clear, but aerosols from the process might have contributed in spreading the metal contaminants outside the industrial compound. Such aerosols may have been released while the pressure vessels were opened (ASS, 1989). Storage of the treated wood products as well as handling of the wastes like sawdust might also contribute to the metal contamination in the surroundings. Chromium in the preservative chemicals is generally reduced from $\mathrm{Cr}$ (VI) to $\mathrm{Cr}$ (III) in the presence of aromatic rings and carbonyl groups in lignin structures (Ostmeyer et al., 1988, 1989) and forms insoluble complexes leading to the fixation of $\mathrm{As}, \mathrm{Cu}$ as well as $\mathrm{Cr}(\mathrm{VI})$ in the wood (Ryberg and Haugen, 1992). Moreover, As, $\mathrm{Cu}$ and $\mathrm{Cr}$ may leach in significant quantities prior to their complete fixation in the freshly impregnated wood.

Metal enrichment for the average contaminated soils at the site, however, follows the order $\mathrm{Cr}>$ $\mathrm{As}=\mathrm{Zn}>\mathrm{Cu}$. Both arsenic and zinc indicate similar enrichment factors in both the grain size fractions of the contaminated soils at the various sectors of the contaminated area. The wooden chip fills mixed with saw dust (WCH) in the area are possibly the remnants of the process wastes, and therefore, a high chromium content is ubiquitous. A significant metal enrichment could also be noted in the organic-rich bottom sediments of the stream (SST) which possibly serve as an effluent from the process platform.

\subsection{Laboratory scale metal removal}

\subsubsection{Sequential leaching batch experiments}

The sequential leaching batch studies on a laboratory scale indicated that the amount of leached metals $\mathrm{As}, \mathrm{Cu}, \mathrm{Cr}$ and $\mathrm{Zn}$ varied considerably with the concentration of OXA and $\mathrm{pH}$ of buffered AMOX solution. In general, the bulk of the contaminant metals were released during the first step of leaching and decreased in the following leachates. The extraction of metals also differed between the two selected soil samples having different $\mathrm{pH}$ values. The amount of the contaminant metals 
(a)

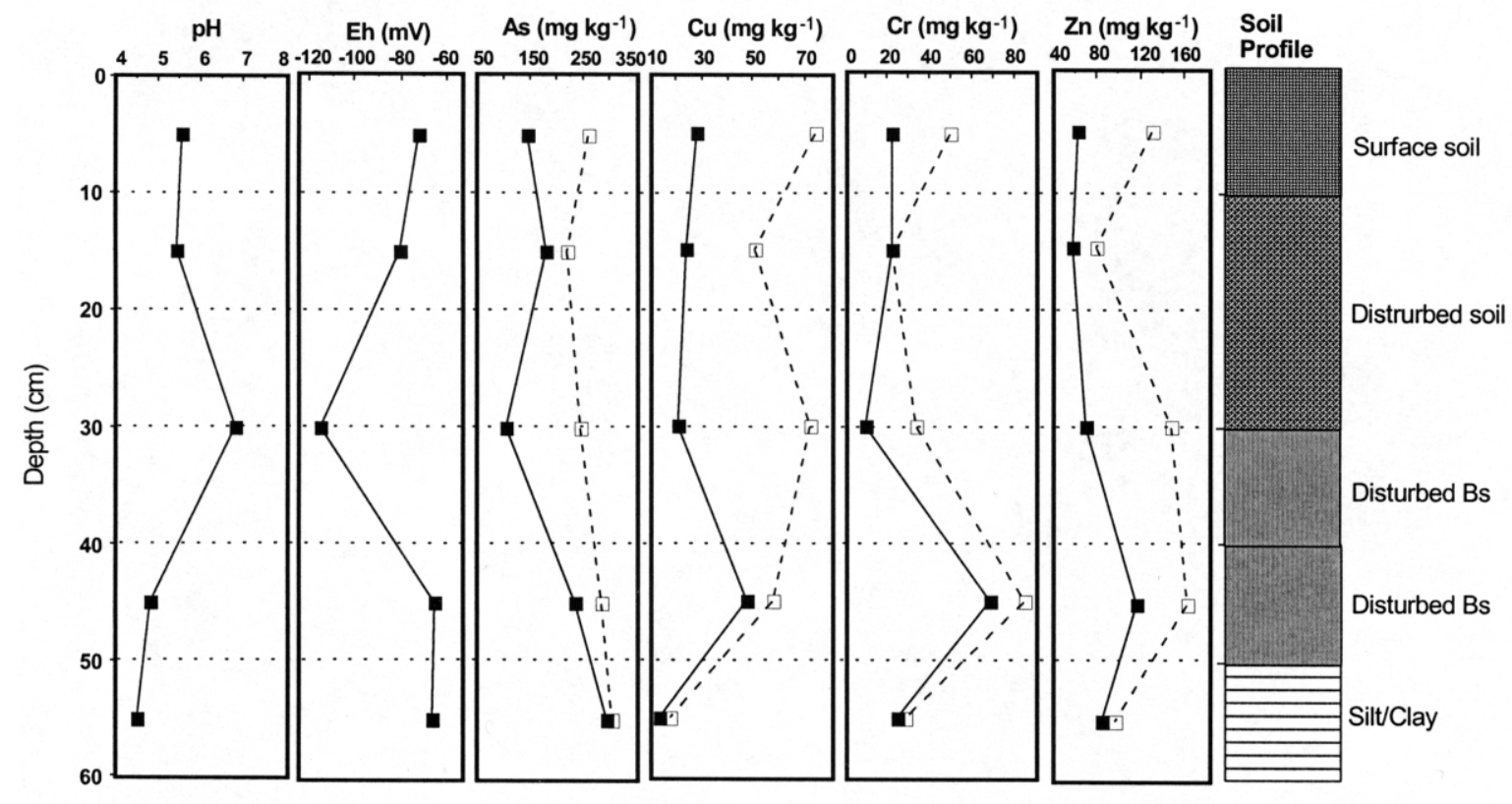

(b)

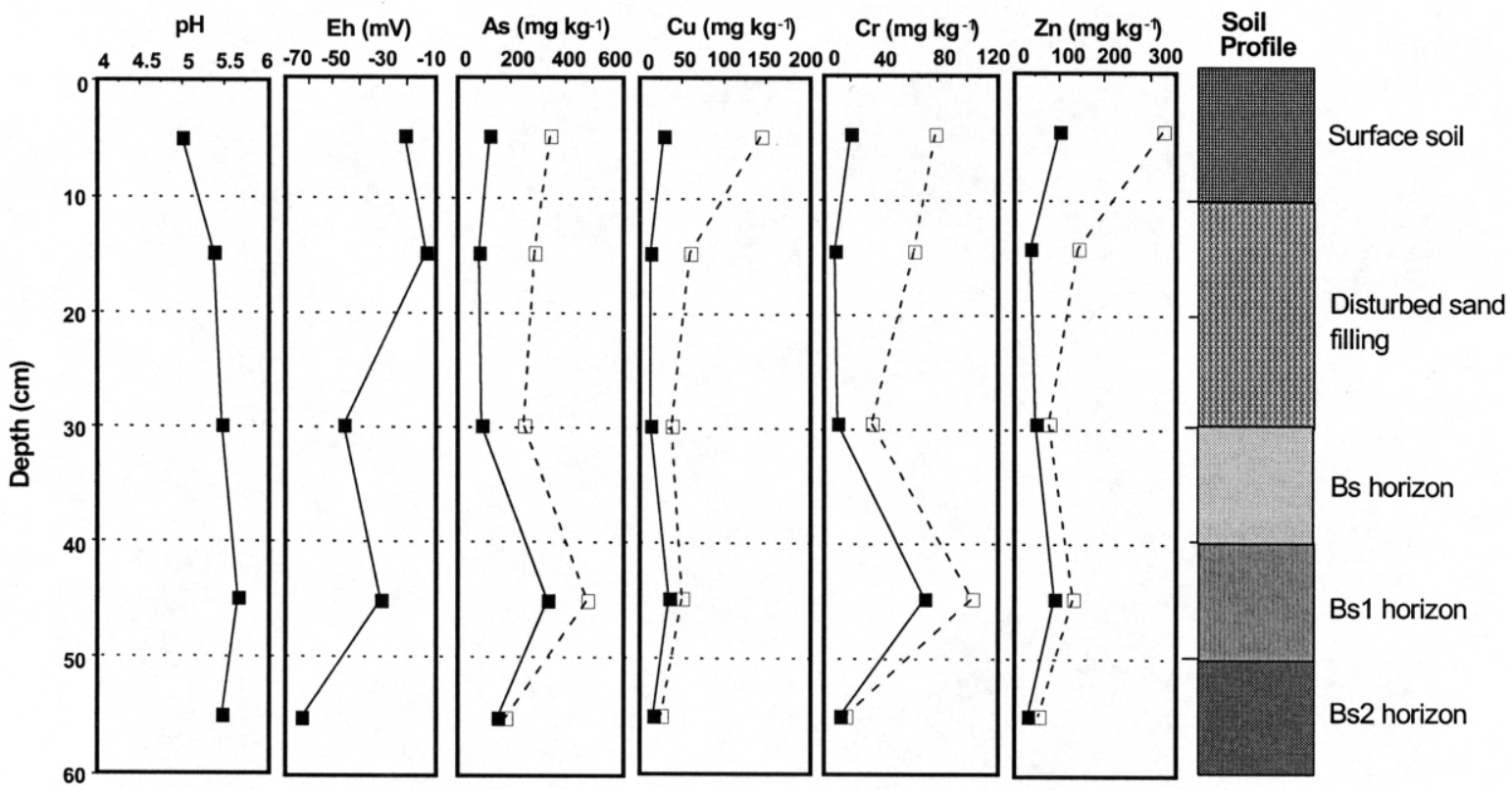

Fig. 4. Variation of $\mathrm{pH}$ and redox (Eh) along with the concentration of $\mathrm{As}, \mathrm{Cu}, \mathrm{Cr}$ and $\mathrm{Zn}\left(\mathrm{mg} \mathrm{kg}^{-1}\right)$ in $<2 \mathrm{~mm}(\boldsymbol{\square}$ solid line) and $<0.125 \mathrm{~mm}$ ( $\square$ dashed line) at two selected soil profiles at (a) NE sector and (b) SW sector of the wood preservation site. 



Fig. 5. Reference soil normalised plot of $\mathrm{As}_{\text {tot }}, \mathrm{Zn}_{\text {tot }}, \mathrm{Cu}_{\text {tot }}$ and $\mathrm{Cr}_{\text {tot }}$ concentration in (a) $<2 \mathrm{~mm}$ and (b) $<0.125 \mathrm{~mm}$ grain size fraction for the contaminated soil samples from the wood preservation site.

retained in the two soils after successive leaching stages are depicted in Fig. 6(a-d) and Fig. 7(ad).

\subsubsection{Quantification of effective removal of metal contaminants}

Sequential leaching of the sample $\mathrm{Kc}-32$ by OXA and AMOX buffered extracts indicated an effective removal of 93-99\% of As (Fig. 6a). Nearly $69-78 \%$ of the As was soluble from the sample Kc-45 by OXA, while the solubility decreased further with increasing $\mathrm{pH}$ of AMOX for both the contaminated soil samples (Fig. 6a and Fig. 7a). A significant correlation was noted between the amount of leached arsenic with $\mathrm{pH}$ of the oxalate medium during the batch experiments.

An effective removal of approximately 56-67\% of $\mathrm{Cu}$ and $\mathrm{Zn}$ was achieved following the sequential leaching of Kc-32 in OXA and AMOX extraction media (Fig. 6b,d). Nearly $78-81 \% \mathrm{Cu}$ and $62-66 \% \mathrm{Zn}$ were leached from the reference soil Kc-45 following OXA extraction (Fig. 7b,d). The removal of $\mathrm{Cr}$ from $\mathrm{Kc}-32$ was rather low (approx. $38-44 \%)$ in all the batch tests. An increased solubility of $\mathrm{Cr}$ was, however, shown by AMOX buffered at pH 1.4 and 2.5 (Fig. 6c). Nearly 98\% of $\mathrm{Cr}$ was removed by $0.7 \mathrm{M}$ OXA from the reference soil Kc-45 and the solubility decreased 

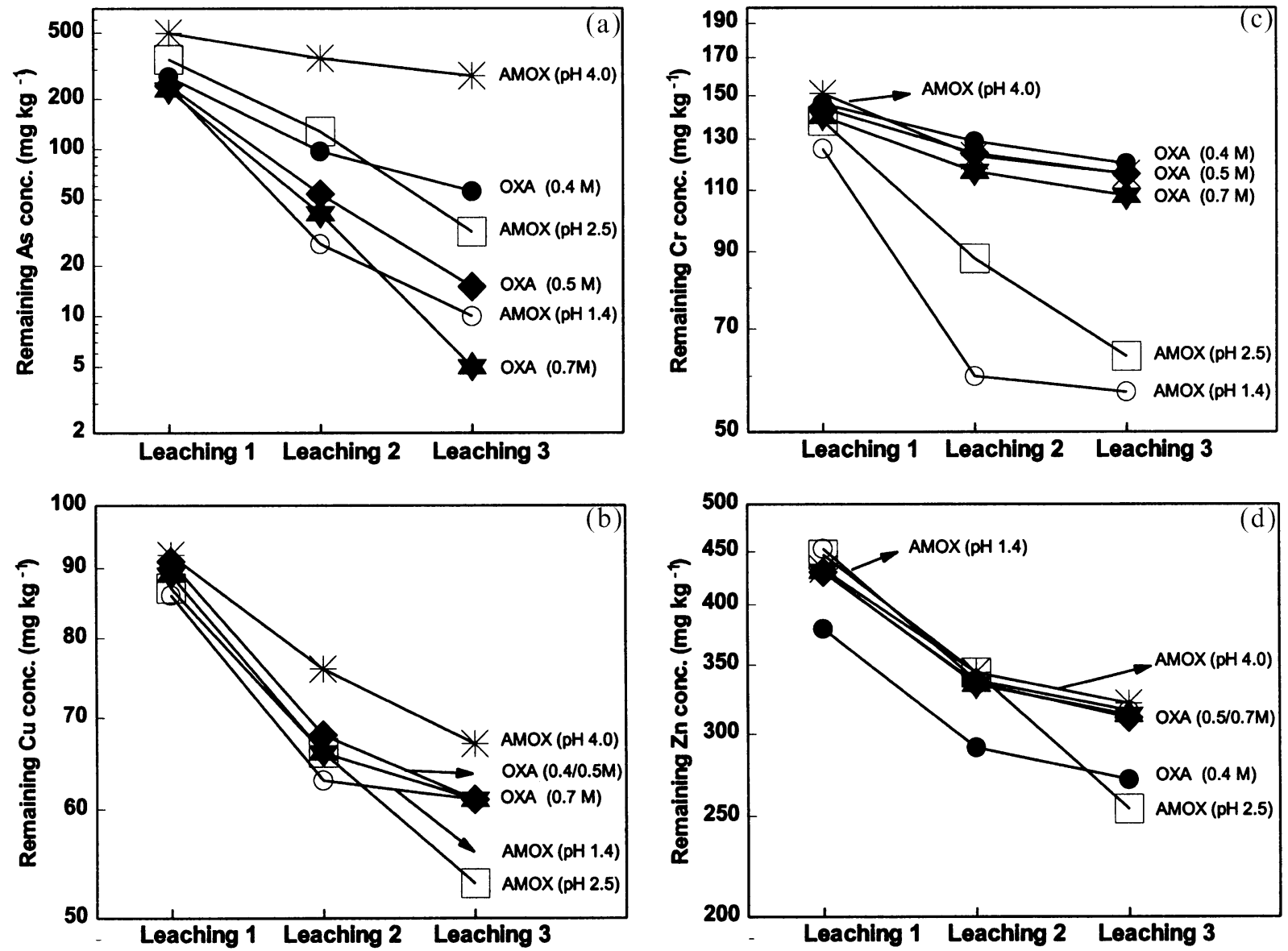

Fig. 6. Remaining metal concentrations in the $<0.125-\mathrm{mm}$ fraction of the Kc-32 soil sample, $\mathrm{pH}=4.9$ after remediation. (a) As $\left(\mathrm{As}_{\text {tot }}=261 \mathrm{mg} \mathrm{kg}^{-1}\right)$; (b) $\mathrm{Cu}\left(\mathrm{Cu}_{\mathrm{tot}}=157 \mathrm{mg} \mathrm{kg}{ }^{-1}\right)$; (c) $\mathrm{Cr}\left(\mathrm{Cr}_{\text {tot }}=193 \mathrm{mg} \mathrm{kg}{ }^{-1}\right)$; and (d) $\mathrm{Zn}\left(\mathrm{Zn}_{\text {tot }}=724 \mathrm{mg} \mathrm{kg}{ }^{-1}\right)$. Note logarithmic scale in the $y$-axis.

gradually through $87 \%$ to $72 \%$ with decreasing OXA concentrations (Fig. 6c and Fig. 7c).

\subsubsection{Mechanisms of metal removal}

The bulk of As in the soils was oxalate-extractable and related quantitatively to the oxalateextractable fractions of $\mathrm{Fe}, \mathrm{Al}$ and $\mathrm{Si}$ in the contaminated soils (Fig. 8). Arsenic solubility was found to be maximum at $\mathrm{pH}$ 0.9-1.4. A reducing agent such as oxalate, releases the oxyanionic inorganic As(V) adsorbed on the poorly ordered and non-crystalline secondary hydrous oxides of $\mathrm{Fe}$ and $\mathrm{Al}$ as well as the ITM materials common in these podsolic soils (Gustafsson et al., 1995). The presence of ITM in these soils has been confirmed by IR spectroscopic studies as well as the ratio of inorganic-Al to Si between 2.4 and 2.6 (Bhattacharya et al., 1996). The removal of $\mathrm{Cu}$ is related to the formation of $\mathrm{Cu}$-oxalate complexes and related to association of $\mathrm{Cu}$ with the organic matter in the soils (Fig. 6b, Fig. 7b). Trivalent $\mathrm{Cr}$ coexisting with the Fe-oxyhydroxides in these soils may also be released due to reductive dissolution at low pH (Sass and Rai, 1987; see Fig. 3). $\mathrm{Zn}$ is often adsorbed to the surface reactive sites of Feoxyhydroxides (Kinniburgh and Jackson, 1982; 

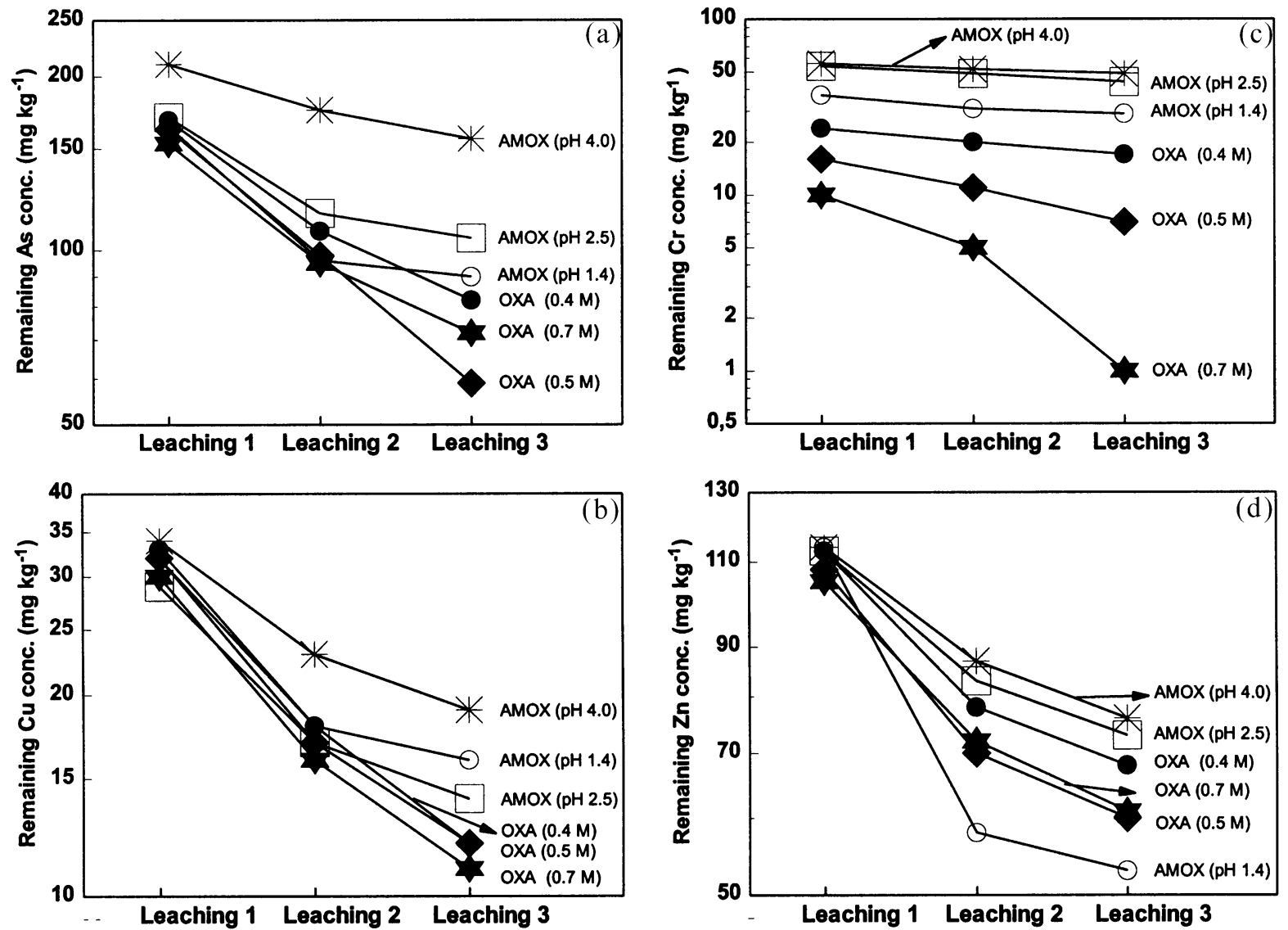

Fig. 7. Remaining metal concentrations in the $<0.125-\mathrm{mm}$ fraction of the $\mathrm{Kc}-45$ soil sample, $\mathrm{pH}=4.9$ after remediation. (a) As

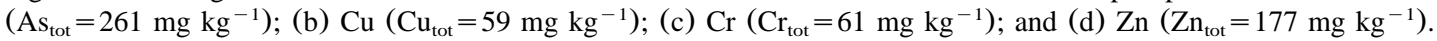

Sadiq, 1991) and may get slowly diffused along the hydrated layers of $\mathrm{Fe}$-oxides leading to the formation of franklinite $\left(\mathrm{ZnFe}_{2} \mathrm{O}_{4}\right)$.

\section{Discussion and conclusions}

\subsection{Mobility and retention of contaminant metals}

The analytical results reveal a large spread of the contaminant metals in the surface soils. The highest concentrations of the contaminant metals were found in the vicinity of the platform on which the chemical treatment was carried out. The distribution of the metals in the soil profiles (Fig. 4) were related to the $\mathrm{pH}$ and the redox conditions of the soil horizons. Concentrations of the contaminant metals were accentuated in the Bs horizons (approx. 40-50 cm). In both the soil profiles, an increase in $\mathrm{pH}$ and concomitant decrease in soil Eh resulted in the mobilisation of As to a greater depth (see Fig. 4a,b). The trivalent As-species was the most mobile and sensitive to the changes in redox conditions. Within the redox interval 0 to $-100 \mathrm{mV}$, inorganic As(V) species were adsorbed onto the surface of the amorphous and poorly crystalline $\mathrm{Fe}$ - and Al-phases at approximately $\mathrm{pH}$ 4.5-5 (Fig. 4a), and therefore, remain immobile (Guo et al., 1997). They can be readily mobilised due to desorption as well as reductive dissolution of the adsorbent phases due to the changes in soil 

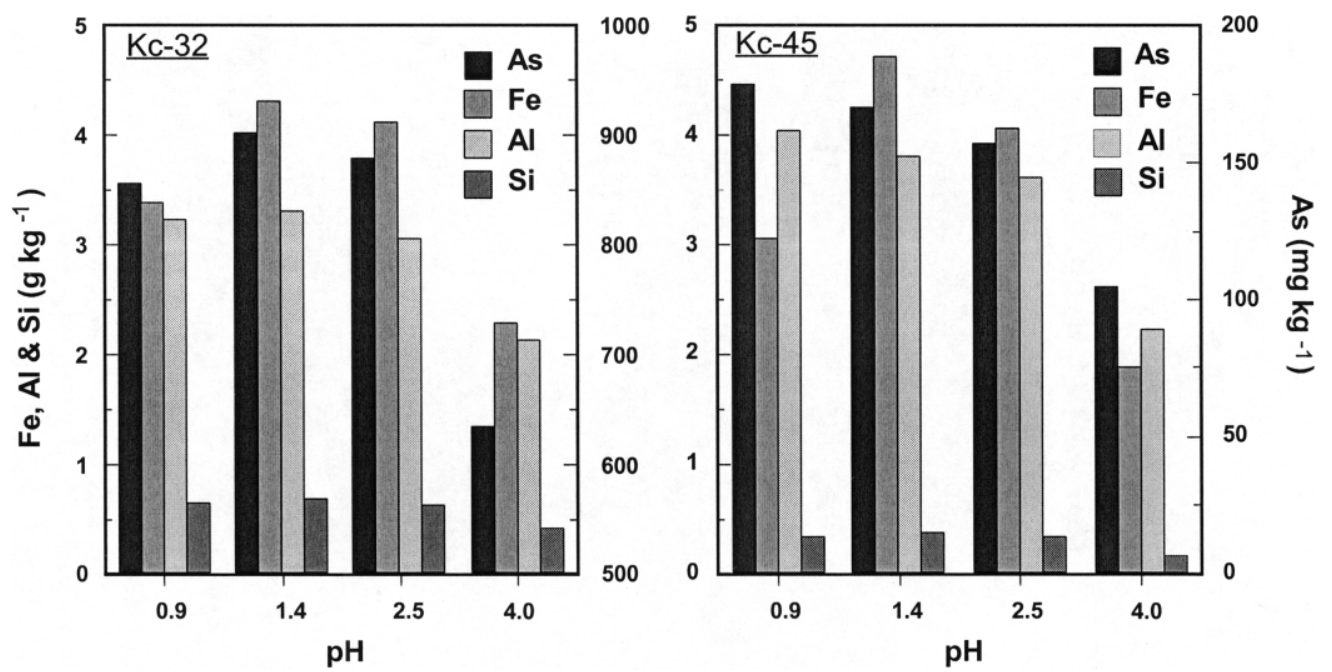

Fig. 8. Relationship between the oxalate leachable fractions of $\mathrm{As}, \mathrm{Fe}, \mathrm{Al}$ and $\mathrm{Si}$ in the contaminated soils with varying $\mathrm{pH}$. Note separate scale for the As concentrations (see text for details).

redox and $\mathrm{pH}$. It is, therefore, important to note that the As can be readily mobilised under reducing conditions within the Konsterud soils.

On the other hand, the acidic character of the soils has favoured the mobilisation of $\mathrm{Cu}, \mathrm{Cr}$ and $\mathrm{Zn}$ which is manifested by their low abundance in the soils and consequent enrichment of these metals in the organic-rich stream sediments. The presence of contaminant metals $\mathrm{As}, \mathrm{Cu}, \mathrm{Cr}$ and $\mathrm{Zn}$ in the stream sediments further indicates their mobilisation from the soils from the contaminated area.

\subsection{Effective remediation technique}

According to the guidelines set up by the Swedish Environmental Protection Board (Naturvårdverket, 1997) and Swedish Institute for Environmental Medicine (Viktorin et al., 1990), soils at the industry-contaminated sites with metal contents above $15 \mathrm{mg} \mathrm{kg}^{-1} \mathrm{As}, 100 \mathrm{mg} \mathrm{kg}^{-1} \mathrm{Cu}$, $120 \mathrm{mg} \mathrm{kg}^{-1} \mathrm{Cr}(\mathrm{III}), 5 \mathrm{mg} \mathrm{kg}^{-1} \mathrm{Cr}$ (VI) and 400 $\mathrm{mg} \mathrm{kg}^{-1} \mathrm{Zn}$ need remediation for sensitive land use. The soil chemical data clearly indicates that the site of the former wood preservation facility is contaminated by As with concentrations nearly four-fold of the guideline values, while the concentrations of $\mathrm{Zn}, \mathrm{Cu}$ and $\mathrm{Cr}$ were much lower.

The present study reveals that the selection of the fine fraction of the soils (i.e. $<0.125 \mathrm{~mm}$ ) is appropriate to handle the contaminated mass for remediation. Laboratory scale experiments using sequential leaching technique have revealed that as much as $98-99 \%$ of the principal contaminant As could be extracted from the soils by leaching with oxalic acid which is biodegradable. Leaching of As and other metals from the contaminated soils increased consistently with decrease in the $\mathrm{pH}$ of the extraction medium $\left(R^{2}=0.70-0.95\right)$. The metals in the leachate could subsequently be separated using different ion exchange media or lime precipitation at a suitable $\mathrm{pH}$ favouring adsorption of both As and other cationic metal species.

\section{Acronyms and abbreviations}

\begin{tabular}{ll}
\hline AMOX & Ammonium oxalate \\
BIS-salt & Boliden-salt \\
CCA & Chromated copper arsenate \\
Eh & Redox potential \\
ICP & Inductively coupled plasma \\
ITM & Imogolite-type material \\
LOI & Loss on ignition \\
OXA & Oxalic acid \\
PCP & Pentachlorophenol \\
SST & Stream sediments \\
WCH & Wooden chips mixed with saw mill dust \\
\hline
\end{tabular}




\section{Acknowledgments}

This study had been carried out as a part of a consultancy project assigned by Kristinehamn Municipality. The authors (P. Bhattacharya and G. Jacks) would like to thank the environmental authorities of the Kristinehamn Community for the partial financial support for this study. Ann Fylkner helped in part of the laboratory studies. Comments by J.P. Gustafsson at the Department of Land and Water Resources Engineering and an anonymous reviewer helped in improving the draft of the manuscript.

\section{References}

Adriano DC. Trace elements in the terrestrial environment New York: Springer, 1986 (p. 533).

Adriano DC, Chlopecka A, Kaplan DI. Role of soil chemistry in soil remediation and ecosystem conservation. Soil Chem Ecosys Health 1998;52:361-386.

Andersen S, Rasmussen G, Snilsberg P, Amundsen CE, Westby T. Assessing toxicity and mobilization of impregnation salts at a contaminated site. Fresenius $J$ Anal Chem 1996;354:676-680.

Andersson A, Nilsson Å, Håkansson L. Metal concentration of the mor layer. Swedish Environmental Protection Agency (SNV) 1991; Report 3990: 85.

Appelo CAJ, Postma D. Geochemistry, groundwater and pollution Rotterdam: A.A. Balkema, 1993 (p. 536).

ASS (National Board of Occupational Safety and Health, Stockholm). Decreased risks in wood preservation. Report 1989 (4) 1989 (p. 106).

Bartlett RJ, James B. Behavior of chromium in soils: III oxidation. J Environ Qual 1979;8(1):31-35.

Bhattacharya P, Nordqvist S, Jacks G. Heavy metals in soils: a case study for potential arsenic contamination in the environment around the site of former wood preservation facility in Central Sweden. In: Aagaard P, Jahren J, editors. The Rosenqvist Symposium on Clay Minerals in the Modern Society, Abstract Volume Rapport nr. 69Inst Geol Univ. Oslo, 1996:9-10.

Bhattacharya P, Chatterjee D, Jacks G. Occurrence of arsenic contaminated groundwater in alluvial aquifers from Delta Plains, Eastern India: options for safe drinking water supply. Int Jour Water Res Management 1997;13(1):79-92.

Bhattacharya P, Frisbie SH, Smith E, Naidu R, Jacks G, Sarkar B. Arsenic in the environment. In: Sarkar B, editor. Handbook of heavy metals in the environment New York: Marcell Dekker Inc, 2001. (in press).

Bhumbla DK, Keefer RF. Arsenic mobilisation and bioavailability in soils. In: Nriagu JO, editor. Arsenic in the environment, part I: cycling and characterisation New York: John Wiley, 1994:51-82.
Bourg ACM. Modélisation du comportement des métaux traces à l'interface solide liquide dans les systèmes aquatiques. Document BRGM 1983; no. 62, Orléans, France (in French).

Cullen WR, Reimer KJ. Arsenic speciation in the environment. Chem Rev 1989;89:713-754.

Eckel WP, Langley WD. A background-based ranking technique for assessment of elemental enrichment in soils at hazardous waste sites. In Super fund '88: Proceedings of the 9th National Conference, Nov 28-30, 1988, Washington, DC Silver Spring, MD: The Hazardous Materials Control Research Institute, 1988:286-288.

Edén P, Björklund A. Geochemistry of till in Fennoscandia from ultra-low density sampling. J Geochem Explor 1995;52:285-302.

Fox TR, Comerford NB. Low-molecular-weight organic acids in selected forest soils of the southeastern USA. Soil Sci Soc Am J 1990;54:1139-1144.

Fristad WE. Case study: using soil washing/leaching for the removal of heavy metal at the twin cities army ammunition plant. Remediation 1995;5:61-72.

Galba J, Polacek S. Sorption of arsenates under kinetic conditions in selected soil types. Acta Fytotech 1973;28:187-197.

Garrels RM, Christ CL. Solutions, minerals and equilibria New York: Harper and Row, 1965 (p. 450).

Guo T, DeLaune RD, Patrick WH. The influence of sediment redox chemistry on the chemically active forms of arsenic, cadmium, chromium and zinc in estuarine sediment. Environ Intl 1997;23(3):305-316.

Gustafsson JP, Bhattacharya P, Bain DC, Fraser AR, McHardy WJ. Podzolisation mechanisms and the synthesis of imogolite in northern Scandinavia. Geoderma 1995;66:167-184.

Hermann R, Neumann-Mahlkau P. The mobility of zinc, cadmium, copper, lead, iron and arsenic in ground water as a function of redox potential and $\mathrm{pH}$. Sci Tot Environ 1985;43:1-12.

Jacks G, Bhattacharya P. Arsenic contamination in the environment due to the use of CCA-wood preservatives. In: Arsenic in Wood Preservatives, Part I. Exemption Substances Project, Swedish National Chemicals Inspectorate. KEMI Report 3/98 1998:7-75.

Kabata-Pendias A, Pendias H. Trace element in soil and plants. Third edition Boca Raton, FL: CRC Press, 2001 (p. 413).

Kedziorek MAM, Bourg ACM. Acidification and solubilisation of heavy metals from single and dual-component model solids. Appl Geochem 1996;11:299-304.

Kinniburgh DG, Jackson ML. Concentration and pH dependance of calcium and zinc adsorption by iron oxide gel. Soil Sci Soc Am J 1982;46(1):56-61.

Koljonen T, editor. Geochemical atlas of Finland, part 2, Till. Geological Survey of Finland 1992 (p. 218).

Lindberg J, Sterneland J, Johansson P-O, Gustafsson JP. Spodic material for in-situ treatment of arsenic in groundwater. Groundwater monitoring and remediation fall 1997:125130.

Lund U, Fobian A. Pollution of two soils by arsenic, chromium and copper, Denmark. Geoderma 1991;49:83-103. 
Manning BA, Goldberg S. Modelling competitive adsorption of arsenate with phosphate and molybdate on oxide minerals. Soil Sci Soc J 1996;60:121-131.

Manning BA, Goldberg S. Adsorption and stability of arsenic (III) at the clay mineral-water interface. Environ Sci Technol 1997;31:2005-2011.

Masscheleyn PH, Delaune RD, Patrick WH. Effect of redox potential and $\mathrm{pH}$ on arsenic speciation and solubility in a contaminated soil. Environ Sci Technol 1991;25:1414-1419.

Naturvårdverket. Generella riktvärden för förorenad mark 1997; Report 4638 (In Swedish), p. 46.

Nordic Council of Ministers. Guidelines for Integrated Monitoring in the Nordic Countries, 1988; p. 31.

Ostmeyer JG, Elder TJ, Winandy JE. Spectroscopic analysis of Southern pine treated with chromated copper arsenate. Part I. J Wood Chem Technol 1988;8:413-439.

Ostmeyer JG, Elder TJ, Winandy JE. Spectroscopic analysis of Southern pine treated with chromated copper arsenate. Part II. J Wood Chem Technol 1989;9:105-122.

Rai D, Eary LE, Zachara JM. Environmental chemistry of chromium. Sci Tot Environ 1989;86:15-23.

Rulkens WH, Tichy R, Grotenhuis JTC. Remediation of polluted soil and sediment: prespectives and failures. Water Sci Technol 1998;37(8):27-35.

Ryberg D, Haugen A. Helsefare ved saltimpregnering med CCA (kobber, krom, arsen). In: Träskyddsinstitutets miljöprojekt 1990-1994, Svenska Träskyddsinstitutet, Stockholm 1992, Report 170: 201-236 (In Norwegian).

Sadiq M. Solubility and speciation of zinc in calcareous soils. Water Air Soil Pollut 1991;57-58:411-421.

Sadiq M, Zaidi TH, Mian AA. Environmental behaviour of arsenic in soils: theoretical. Water Air Soil Pollut 1983;20:369-377.

Sass BM, Rai D. Solubility of amorphous chromium(III)iron(III) hydroxide solid solutions. Inorg Chem 1987;26:2228-2232.
Saxen PK, Krishnaraj S, Dan T, Perras MR, Vettakkorumakankav NN. Phytoremediation of heavy metal contaminated and polluted soils. In: Prasad MNV, Hegemeyer J, editors. Heavy metal stress in plants Berlin: Springer, 1999:305.

Smal H. Acidification and its long term impact on metal mobility. In: Salomons W, Stigliani WM, editors. Biogeodynamics of pollutants in soils and sediments Netherlands: Hoofdorp, 1994:159-176.

Stephens RW, Brudermann GE, Morris PI, Hollick MS, Chambers JD. Value assessment of the Canadian pressure treated wood industry. SSC Contract No. 4Y002-3-0187/01-SQ. Rept prepared for Natural Resources Canada, Ottawa, Ont, Canada; 1994.

Stilwell DE, Gorny KD. Contamination of soil with copper, chromium, and arsenic under decks built from pressure treated wood. Bull Environ Contam Toxicol 1997;58:2229.

Tamm O. Meddelande Statens Skogsförsöksanstalt 1932;27:1 20. (In Swedish).

Tessier A, Campbell PGC, Carignan R. Influence du pH sur la spéciation et la biodisponibilité des métaux. T.S.M. L'Eau 1985;2:69-73. (in French).

Tipping E. Modelling ion-binding by humic acids. Colloid Surf A: Physicochem Eng Aspects 1993;73:117-131.

Viktorin K, Dock L, Vahter M, Ahlborg UG. Hälsoriskbedömning av vissa ämnen i industrikontaminerad mark. IMM Report 1990;4/90:37. (In Swedish).

Warner JE, Solomon KR. Acidity as a factor in leaching of copper, chromium and arsenic from CCA-treated dimension lumber. Environ Toxicol Chem 1990;9:1331-1337.

Yan Chu H. Arsenic distribution in soils. In: Nriagu JO, editor. Arsenic in the environment, part I: cycling and characterisationJohn Wiley, 1994:17-49. 